${ }^{7}$ Christie, A. B. \& Train, J. B. (1984) Change in the pattern of care for the demented. British Journal of Psychiatry, 144, 9-15.

${ }^{8}$ Rossor, M. N., IVERSEN, L. L., ReYnolds, G. P., MountJoy, C. Q \& RoTH, M. (1984) Neurochemical characteristics of early and late onset types of Alzheimer's disease. British Medical Journal, 288, 961-964.
${ }^{9}$ Christie, A. B. \& Wood, E. R. M. (1988) Age, clinical features and progress in SDAT. International Journal of Geriatric Psychiatry, 3, 63-68.

${ }^{10}$ Scottish House and Health Department (1980) Scottish Health Authorities Priorities for the Eighties (SHAPE) A report by the Scottish Health Service Planning Council. Edinburgh: HMSO 1980: 31 .

\title{
College Research Unit
}

Council has recently approved the appointment of Professor John Wing as the first Director of the College's Re- search Unit. Professor Wing will take up this post in 1989.

R. G. PrIEST, Registrar

\section{Obituary}

Editor: Henry R. Rollin

James Christopher Penton, formerly Director, Army Personnel Research Establishment

Dr James Christopher Penton, a Foundation Fellow of the College, died on 18 November 1987 in St Lawrence's Hospital, Bodmin. Earlier in his career he had been Assistant Director of Army Psychiatry and, after returning to civilian life, Head of the Psychology Section at the Army Operational Research Group in West Byfleet and later Director of the Army Personnel Research Establishment at the Royal Aircraft Establishment in Farnborough.

Christopher Penton was born in 1910 and, after school at Repton, he went up to New College, Oxford in 1928 and later to the Middlesex Hospital. He took an Honours degree in Physiology and graduated BA, BM, BCh (Oxford) in 1935 and MA in 1963. After house jobs in the East London Children's Hospital and at Queen Mary's Hospital, Stratford, he specialised in psychiatry, returning to Oxford as assistant medical officer at Littlemore Mental Hospital. He took the DPM in 1940 and joined the Royal MedicoPsychological Association in January 1941. From 1942 to 1948 he served in the RAMC and rose to the rank of Lieutenant-Colonel and Assistant Director of Army Psychiatry. After returning to civilian life, he continued his work for the War Office, first as Head of the Psychology Section of the Army Operational Research Group at West Byfleet (from 1948 until 1963) and later (from 1964 until 1971) as Director of the Army Personnel Research Establishment at the Royal Aircraft Establishment in Farnborough, Hants. During all this time he played an important part in developing the techniques of personnel selection, particularly those used in choosing candidates for officer training. After he retired from that job he went to live in Cornwall where he returned to clinical work as Assistant
Psychiatrist at St Lawrence's Hospital, Bodmin from 1972 to 1975.

Christopher Penton will be remembered by his friends, not only for his colourful personality, but as among the most courteous, kind, civilised and cultured of men. He carried with him something of his Oxford background throughout his life. Among his many and varied interests was a keen love of music. He was an accomplished pianist and he could be often seen at performances of Handel's operas by the Handel Opera Society in Sadler's Wells. He was also an enthusiastic and knowledgeable Wagnerite, a combination which shows something of the range and catholicity of his musical tastes. He was an excellent host and an outstanding cook and gardener. He was also a keen folk dancer, and the strength of his personality and powers of persuasion are well exemplified by his success in organising regular lunch-time sessions of country dancing for the War Office personnel in West Byfleet when he served there. Later in life he established a group of Morris Dancers in Cornwall and remained an active member into old age.

He was a regular attender at the yearly meetings of the British Association for the Advancement of Science (always affectionately referred to by him as "The British Ass") and was also an Associate of the British Psychological Society.

Christopher married late at the age of 42 , Nancy E. Ewart, a gifted artist. They had a very happy life together which was cruelly cut short by her illness and early death. Christopher will be remembered with affection by his friends, not only for his unique personality and wideranging interests, but for his innate kindness. His life-long interest in social and community psychiatry continued after he retired from his work for the War Office (by then the Ministry of Defence) in his clinical work at St Lawrence's Hospital in Cornwall. 